\title{
Evaluation of forest fragmentation with particular reference to landscape-based ecological assessment and wildlife conservation
}

\author{
Derya Gülçin a,* (i), K. Tuluhan Yılmaz ${ }^{\mathrm{b}}$ (i)
}

\begin{abstract}
Landscapes are composed of diverse units that associate with each other, and these units have different functions both in ecology and physiognomy. Thus, evaluating landscape character plays an important role for conserving bio-diversity, as well as spatial planning and management of habitats and landscapes. Determining and analyzing environmental factors is an important part of assessing the conservation value of landscape types. For its ecological value, stone pine, botanical name Pinus pinea $\mathrm{L}$. was chosen to be evaluated according to the environmental parameters in this research, because of its scattered distribution around the Mediterranean basin. Although P. pinea L. does not have a widespread distribution, it is naturally found in five regions of Turkey. This research was conducted in three provinces (Muğla, Denizli, and Aydın), located in western Anatolia. Maps representing different classes of soil, geology, aspect, and slope were overlaid in ArcMap 10.5, and characterized by Landscape Character Assessment (LCA). A total of 309 character types were determined, according to tree species composition, represented by 4 variants of the $P$. pinea L. community. To assess fragmentation among 34 different stands, landscape metrics were calculated using Fragstats v4.2 software. Potential range for regenerating stone pine stands was suggested in this paper, which can be considered as habitat corridors providing connectivity between mature stands. Spatial variation in bird species composition, reflecting wildlife richness, was evaluated as evidence for forest fragmentation.
\end{abstract}

Keywords: Landscape ecology, Landscape character assessment, Landscape metrics, Environmental factors, Wildlife richness

\section{Orman parçalanmasının yaban hayatı koruması ve peyzaj ekolojisi temelinde değerlendirilmesi}

\begin{abstract}
Özet: Peyzajlar, birbirleriyle ilişki içinde olan çeşitli peyzaj birimlerinden oluşur. Bu birimler hem ekolojik hem de fizyolojik açıdan farklı işlevlere sahiptir. Peyzaj birimlerinin çeşitli işlevlere sahip olması; peyzaj karakterinin değerlendirilmesi, biyolojik çeşitliliğin korunması, mekânsal planlama, habitat ve peyzaj yönetiminde önemli rol oynamaktadır. Peyzaj birimlerinin sağladığı fonksiyonların yanında onlara etki eden çevresel faktörlerin belirlenmesi ve analiz edilmesi, peyzaj tiplerinin koruma değerinin ortaya konmasını sağlar. Bu araştırmada, ekolojik değeri ve Akdeniz havzasındaki parçalanmış dağılımı ile ön planda olan fistık çamı (Pinus pinea L.) çevresel değişkenlere göre değerlendirilmiştir. Batı Anadolu'da geniş bir yayılışa sahip olan P. pinea L. Muğla, Denizli ve Aydın olmak üzere üç il sınırı içinde peyzaj karakter analizi yöntemi ile incelenmiştir. Bu türün mekânsal yayılışının en yüksek olduğu peyzaj kümesi ise peyzaj metrikleri ile değerlendirilmiştir. $P$. pinea L. topluluğunun 4 varyantı ile temsil edilen ağaç türleri kompozisyonunun veri altlığı olarak kullanıldığı analiz sonucunda çevresel değişkenleri temsil eden toplam 309 karakter tipi elde edilmiştir. 34 farklı meşcere arasındaki mevcut parçalanmayı değerlendirmek amacıyla Fragstats v4.2 yazılımı kullanılmışıı. Bu araştırmanın sonucunda, $P$. pinea L.'nin rejenerasyonu için habitat koridorları arasında bağlantı sağlayabilecek potansiyel alanlar haritalanmıştır. Ayrıca, yaban hayatı zenginliğini yansıtan kuş türlerinin kompozisyonundaki mekânsal değişim, orman parçalanmasının araştırılmasında bir gösterge niteliği taşıdı̆̆ için incelenmiştir.

Anahtar kelimeler: Peyzaj ekolojisi, Peyzaj karakter analizi, Peyzaj metrikleri, Çevresel faktörler, Yaban hayatı zenginliği
\end{abstract}

\section{Introduction}

The composition of landscape is complex, and also associated with different components and units shaped by both natural and anthropogenic features (Forman, 1995; Fischer and Lindenmayer, 2007). Landscapes can be evaluated from several perspectives (Zube et al., 1982; Hirsch and O'Hanlon, 1995). Regarding the analysis of landscape, quantitative indicators allow researchers to measure and assess main characteristics of landscape structure (Haines-Young and Chopping, 1996; Cook, 2002). These characteristics of landscapes are identified by landscape metrics which reveal the structure and fragmentation pattern of landscapes (McGarigal and Marks, 1995; McGarigal et al., 2009). The diversity of landscapes may be changed according to the structure, composition, and function of landscape elements. Consequently, landscape diversity is a function of the number of different patch types, patch shape, and patch size within a landscape mosaic, and also the spatial arrangement of different patch
$凶$ a Aydın Adnan Menderes Üniversitesi Ziraat Fakültesi Peyzaj Mimarlı̆̆ı Bölümü, Aydın

b Çukurova Üniversitesi Mimarlık Fakültesi Peyzaj Mimarlığı Bölümü, Adana

@ * Corresponding author (İletişim yazarı): derya.yazgi@adu.edu.tr

$\checkmark \quad$ Received (Geliş tarihi): 04.12.2019, Accepted (Kabul tarihi): 16.03 .2020
Citation (Atıf): Gülçin, D., Yılmaz, T., 2020. Evaluation of forest fragmentation with particular reference to landscape-based ecological assessment and wildlife conservation. Turkish Journal of Forestry, 21(1): 84-93. DOI: $10.18182 / \mathrm{tjf} .654954$ 
types and interaction between them, in other words, connectivity among these patches (Taylor et al., 1993; Goodwin and Fahrig, 2002). For instance, Rosati et al. (2010), tested the impact of patch size and isolation, on Quercus cerris forest, and concluded that the correlation between species richness and patch area was positive. Landscape diversity types have various functions, both in ecology and physiognomy (Bojie and Liding, 1996; Qian et al., 2018). Therefore, their assessment contributes to landscape ecology and spatial planning studies, for conserving bio-diversity, as well as management of habitats and landscapes (Fahrig, 2003; Kim and Pauleit, 2007). To analyze landscape diversity, different diversity indices have been developed and continually refined (McGarigal and Marks, 1995; Riitters et al., 1995; Cushman et al., 2008).

Landscape metrics are mostly used to determine the structures of landscape units. These units differ in size, shape, number, type, and configuration (Uuemaa et al., 2009; Lausch et al., 2015). Identifying the spatial distribution of these units is an indispensable part of ecological studies for gaining a deeper understanding of landscape composition as well as for finding out connections, relations, processes, and flows occurring within the landscape as a whole (Dušek and Popelková, 2017). By means of European Landscape Convention, the significance of landscape character has been highlighted in terms of protection of landscapes (Prieur et al., 2006). In this context, Landscape Character Assessment (LCA) has been developed and used as an evaluation tool in many European countries (Swanwick, 2002; Wascher, 2005; Brabyn, 2009). LCA is a process that enables researchers to identify both landscape character and ecological value of landscapes, and helps to describe the variation in the character of the landscape (Tudor, 2014; Yazgi and Yilmaz, 2017). It seeks to explain the unique combination of landscape units that make landscapes distinguished (Tudor, 2014). When the landscape is classified in types and spatial units, it is possible to gain a better understanding of the complexity, variety, and continuity of landscape units (Antrop and Eetvelde, 2017; Simensen et al., 2018).

Environmental factors have strong impacts on the distribution of landscape types (Ashcrof et al., 2011). For identification and analysis, these factors are significant in terms of finding out their conservation values. The distribution of Pinus pinea L. is difficult to map because of its scattered pattern around the Mediterranean basin (Richardson, 1998; Abad Viñas et al., 2016). Stone pine (Pinus pinea L.) is a well-known species for its ecological, economic, and cultural roles (Boutheina et al., 2013). $P$. pinea L. may be seen from Portugal to Syria, and it is more abundant in south-western Europe (Iberian Peninsula, South France, Italy), where its regeneration is natural. It is also present along the shores of the Black Sea (Abad Viñas et al., 2016).

In Turkey, $P$. pinea L. is naturally found in BergamaKozak, Aydın-Koçarlı, Antalya-Side, around the Marmara Sea, the coast of Gemlik Gulf, Önsen and Hacıağalı villages in Kahramanmaraş, Artvin and Trabzon in the Black Sea Region (Zohary, 1973; Varol, 2004). P. pinea L. forests are represented by Diantho tripunctati-Pinetum pineae in Muğla, Lavandulo cariensis-Pinetum pineae in Yalova, Crucianella-Pinetum pinea in Trabzon and Artvin and Gastridio ventricosi-Pinetum pineae associations in Kahramanmaraş. P. pinea L. forests are found locally in
Koçarlı (Aydın) as well as Muğla and Denizli (Varol and Tatli, 2002; Varol et al., 2003; Varol, 2004; Varol and Tel, 2010).

$P$. pinea $\mathrm{L}$. has been assessed according to climate variables in the Mediterranean basin, for making evaluations with different aspects (Loewe and Delard, 2012; Muñoz et al., 2015). The history of forest communities in the Mediterranean is a history of forest fragmentation, degradation and eventually deforestation, but also of temporary natural expansion of the forests. Di Castri (1981) stated that the strong and long-lasting human pressure has even caused co-evolution of tree species with man, over perhaps a period of one hundred thousand years (ScarasciaMugnozzaa et al., 2000). More than one century before, climatic characteristics and dendroclimatic studies of this species were revealed with some ecological aspects (Romero and Gilsanz, 1888; Akkemik, 2000). Although cultivation conditions of $P$. pinea $\mathrm{L}$. were investigated in previous studies, landscape characterization is required now to examine the environmental factors which are effective in the distribution of the fragmented species in the Mediterranean basin. For this reason, $P$. pinea $\mathrm{L}$., which is an ecologically valuable species in the Mediterranean landscape, was chosen in this research to be evaluated according to environmental parameters. This paper is focused on the fragmented distribution of $P$. pinea L., with evaluation of four environmental parameters (soil, geology, slope, and aspect), using the LCA method between Muğla and Aydın where natural distribution exists, and landscape metrics in three provinces (Muğla, Denizli, and Aydın) located in western Anatolia.

Forest fragmentation is one of the causes of ecosystem degradation throughout the world (Saunders et al., 1991; Laurance et al., 2002). It may be defined as a process which breaks up intact forested cover into smaller isolated patches through environmental and anthropogenic effects (Wilcove et al., 1986; Davidson, 1998; Bogaert et al., 2011). Environmental effects such as climate change (Hamrick, 2004; Trumbore et al., 2015), forest fire (Alencar et al., 2015), air pollution, soil erosion and sedimentation (Forman and Deblinger, 2000); and human activities such as logging (Broadbent et al., 2008), pesticide use for intensified agricultural practices, and road construction (Forman and Alexander, 1998; Liu et al., 2014), have resulted in forest degradation over time. Fragmentation has an adverse impact on ecosystem services, and their functions (Rocha-Santos et al., 2016; Chakraborty et al., 2017). Inevitable consequences of forest fragmentation are biodiversity and habitat destruction.

The degradation and habitat loss have been accused of threatening endangered species. The most critical form of habitat degradation is fragmentation which is the reduction of continuous habitat into smaller units, spatially distinct patches immersed within a dissimilar matrix. It was reported that $27 \%$ of mammalian species are at great risk of extinction in global scale (Crooks et al., 2017). Forest fragmentation can drastically increase the risk of extinction of endangered felid species, as well as other mammals (Farias et al., 2015). The Anatolian leopard (Panthera pardus tulliana) being one of them, has an unknown status about whether the species has become extinct or not. Nevertheless, it is categorized as Critically Endangered; according to the last known record in Turkey, which was the finding of fresh faecal pellets in 1992 in the western Taurus. The leopard 
formerly occurred across most of Turkey, but particularly in the western Anatolia. Birds occur in all major habitat types; some generalist species may utilize several habitats but many specialist species are confined to just one. Forests are by far the most important habitat supporting $77 \%$ of all bird species (BirdLife Int., 2018). Habitat fragmentation may cause severe impact on specialist species rather than generalist species. Therefore occurrence of specialist bird species may be useful for detecting habitat quality with particular reference to fragmentation.

Forest fragmentation has been evaluated with landscape metrics in diverse studies in an ecological framework (Hargis et al., 1999; McAlpine and Eyre, 2002; Midha and Mathur, 2010). Fragstats software enables researchers to make spatial analysis, and thereby it can produce area, edge, shape, and nearest neighbor metrics (McGarigal and Marks, 1995; Schnell et al., 2013). Specific landscape metrics, such as largest patch index (LPI) and patch density (PD), have been considered robust for measuring fragmentation (Wang et al., 2014). Quantifying landscape structure with landscape metrics can be useful for acquiring spatially consistent findings, which provide biophysical processes driving landscape fragmentation (Sulieman, 2018). The use of simple metrics, instead of complex and usually correlated metrics is an unsettled issue of debate in landscape ecology studies (Bogaert et al., 2011).

Environmental conditions determine vegetation structure, composition, and function of forests (WilliamsLinera, 1990). Previous studies have focused on forest disturbances as a result of changing environmental conditions. Variation in these conditions may affect forests by altering the frequency, intensity, duration, and timing of natural disasters (Dale et al., 2001). For instance, Picea abies forest stands in the National Nature Reserve Oppkuven were assessed in different aspects, which proved that aspect as an environmental condition had altered stands' species composition. Therefore, one of the causes on forest fragmentation may be explained by effects that shaped with environmental factors.

\section{Materials and methods}

The research area is located in the Aegean region, bordered by the Aegean Sea in the western part of Turkey, which gives the region its name. Semi natural, natural, and urban landscapes within the boundaries of Aydın, Denizli, and Muğla provinces, constitute the material of this research bounded by $37^{\circ} 21^{\prime}-37^{\circ} 85^{\prime}$ north, and $27^{\circ} 84^{\prime}-29^{\circ} 08^{\prime}$ east coordinates (Figure 1). The surface of area covers approximately $110.800,00 \mathrm{~km}^{2}$.

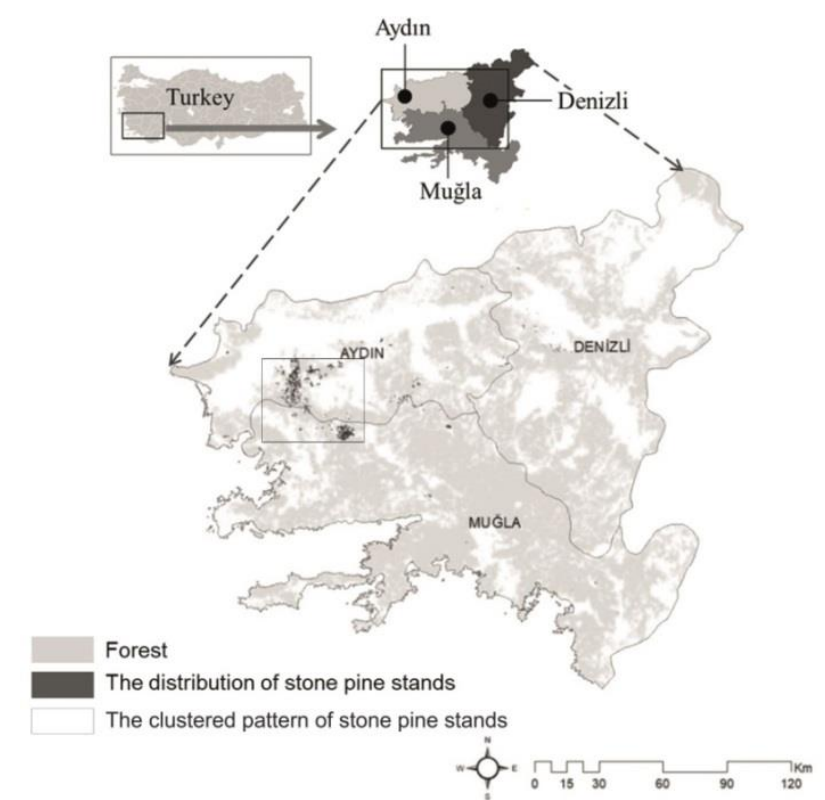

Figure 1. Geographic distribution of stone pine forests (Pinus pinea L.) showing the research area of Aydin, Denizli, and Muğla Provinces

There are various landscape types in the research area, by agricultural fields on fertile soils of Meander plain and forests, which has an important role in social forestry. Furthermore, this area comprises urban and rural settlements, and tourism sites along the coast; nature conservation areas, such as Dilek Peninsula National Park (in Kuşadası district of Aydın Province), and Bafa Lake Nature Park (within the boundaries of Milas district of Muğla Province); forests, and the lower catchment of Great Meander. The Meander Delta is integrated with Lake Bafa. This natural area, which is the result of the closure of the old sea gulf by the alluvium brought by the Menderes River, is a nature park which is important for the reproduction of certain bird species. The vegetation of the area is mainly composed of semi-natural olive orchards (Olea europae L.), Mediterranean maquis and frigana communities, and forests of Turkish pine, botanical name Pinus brutia Ten. (Seçmen and Leblebici, 1982; Kete et al., 2005). Tree species representing forest communities include Turkish pine (Pinus brutia Ten.), juniper (Juniperus spp.), stone pine (Pinus pinea L.), black pine (Pinus nigra J.F. Arnold.), oak (Quercus spp.), Lebanon cedar (Cedrus libani A. Rich.), aspen poplar (Populus tremula [Michx.] Á. Löve \& D. Löve), and Oriental sweetgum (Liquidamber orientalis Miller). Other species are composed of walnut (Juglans regia L.), chestnut (Castanea sativa Mill.), almond (Prunus dulcis Mill.), plane tree (Platanus orientalis Linn.), alder leaf (Alnus orientalis Decne.), poplar (Populus spp.); and two exotics: pseudoacacia (Robinia pseudoacacia L.), and eucalyptus (Eucalyptus camaldulensis Dehnh.). Stone pine forests are found locally in Aydın as well as Muğla and Denizli in the entire research area.

The research area has been an important site presenting habitat for the Anatolian leopard. Kumerloeve (1975) stated that between 1930 and 1950 the leopard hunter Hasan Mantoluoglu, who lived in Milas, located in the current research area, hunted about 50 leopards. In fact, literature reviews show that the leopard has the widest habitat 
tolerance in diverse regions of the world. Their habitats are mostly woodlands and forests. It is interesting that from India to Southeast Asia, P. pardus have been encountered in all forest types, from tropical rainforest to the temperate deciduous and alpine coniferous (Başkaya, 2003). Recently, it is predicted that it may exist in the mountains of the Black Sea coast and south-westwards of the Taurus Mountains (Başkaya and Bilgili, 2004). Nevertheless no evidence has been provided for its actual occurrence by the scientific authorities.

The diverse structure of vegetation occurs in the research area provides a habitat mosaic utilized by various bird species. Earlier attempts to study the avian fauna of the research area reveal that 57 bird species were recorded while 22 of them were directly associated with the $P$. pinea L. forest (OSIB 2014).

\subsection{Research methodology}

The aim of this research was to assess the fragmentation of stone pine ( $P$. pinea $\mathrm{L}$.) forests, using landscape metrics and typology, and provide interconnected relationships with fragmentation and wildlife conservation. Datasets obtained from ASTER Global Digital Elevation Model, were used to complete this analysis. Maps used included a forest map showing spatial distribution of stands of three provinces, and maps representing different classes of environmental factors (soil, geology, aspect, and slope). Four thematic maps were overlaid in ArcMap 10.5, and characterized by LCA. To assess fragmentation among 34 different stands, landscape metrics were calculated using Fragstats v4.2 software (McGarigal and Marks, 1995). Fragmentation amongst the different stands of stone pine in the research area is shown in Figure 1. They are clustered in the southwestern part of Aydin province and in the northwestern part of Muğla province. Due to the fragmented pattern of the stands, the forest structure was defined with landscape metrics, taking into consideration environmental factors. Hence, four thematic maps were used to understand how these stands were distributed in the area, and how was the typology of landscape complex covering stone pine stands.

Once a comprehensive literature review was completed, then, the distribution of stone pine forests could be examined in the research area. The vector maps of soil groups and geological formation were acquired from the Muğla General Directorate of Forestry, and the Municipal Hall of Aydın. The mosaic format of digital elevation map was used to produce slope and aspect maps. Following that, both maps were reclassified, and a zonal statistic tool of ArcMap 10.5 was utilized to weight the pixels. These maps were then converted into vector format via a software conversion tool. Four thematic maps were overlaid in ArcMap 10.5 and characterized by LCA, and then units representing these maps were coded, as presented in Figure 2. The outputs of LCA were evaluated according to their frequency values, and the comparative results were discussed. Another method that applied for the assessment of the distribution of stone pine was landscape metrics. To assess fragmentation among 34 different stands, landscape metrics were calculated using Fragstats v4.2 software. When the results were compared, the proposal for the regeneration of $P$. pinea $\mathrm{L}$. forest was created. Additionally, bird census data, compiled from two locations within the research area
(OSIB, 2014) was compared, and bird species composition was evaluated as an indicator of forest fragmentation.

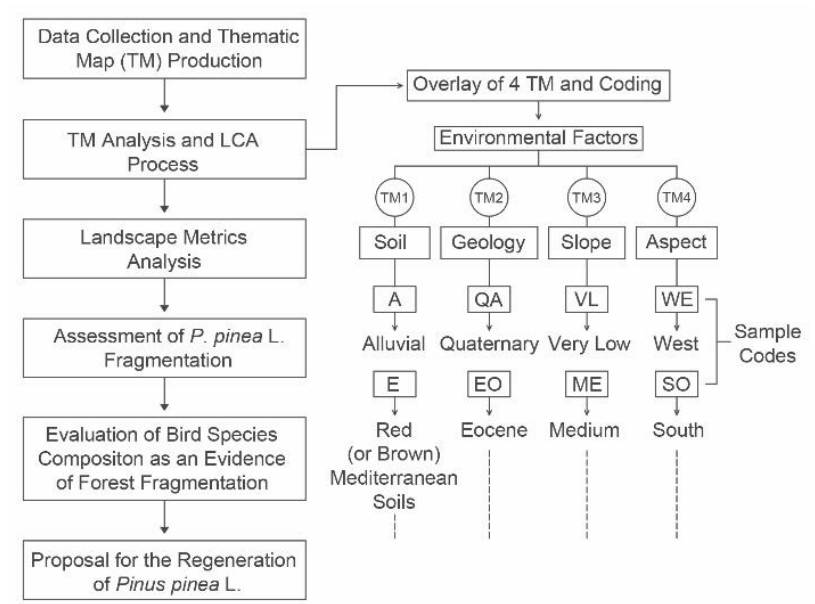

Figure 2. Research methodology

\section{Results}

As a result of the LCA, 309 character types were determined, represented by 4 variants of the $P$. pinea. L. community (Pure stands: Cf; Stands mixed with P. brutia: $\mathrm{CfCz}$; Stands mixed with Quercus spp.: CfM; Stands mixed with $C$. libani: CfS). Areas of low frequency, under the average size of total patches, were discarded from the analysis. There was a positive correlation between their area and frequency, of 0,322 R-square value, when linear regression analysis was applied (Figure 3 ).

The dramatic change of frequency values shows that some of the landscape types are clustered in specific areas while others are fragmented. Due to their fragmentation, the landscape connectivity is low when compared with the clustered pattern of the patches. The values belonging to these patches are represented in Table 1 .

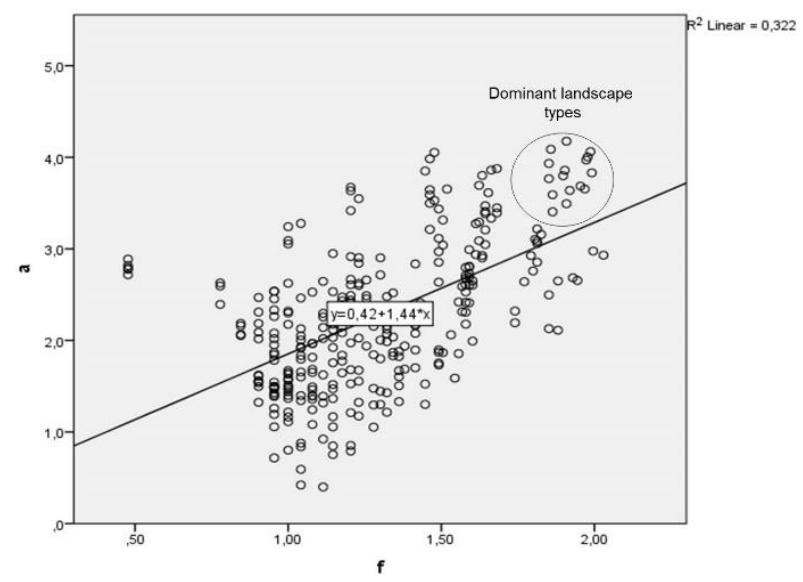

Figure 3. Frequency and logarithmic scale values for the area of each landscape type (a: area, $f$ : frequency) 
Table 1. Frequency and mean size of dominant landscape types (N: Non-calcareous brown forest soil, U: Lime-free soil, PA: Paleozoic, TR: Trias, ME: Medium, EA: East, WE: West, NO: North, SO: South)

\begin{tabular}{ccc}
\hline Landscape Types & Area (ha) & Frequency (n) \\
\hline N_EO_ME_WE & 483.1 & 85 \\
N_PA_ME_WE & 14869.3 & 81 \\
N_TR_ME_EA & 3111.6 & 81 \\
N_TR_ME_WE & 7207.5 & 80 \\
U_EO_ME_EA & 451.7 & 88 \\
U_EO_ME_NO & 446.1 & 76 \\
U_EO_ME_SO & 852.2 & 107 \\
U_EO_ME_WE & 945.9 & 99 \\
U_PA_ME_EA & 6259.4 & 79 \\
U_PA_ME_NO & 4840.1 & 90 \\
U_PA_ME_SO & 9273.6 & 94 \\
U_PA_ME_WE & 11441.1 & 97 \\
U_TR_ME_EA & 4497.3 & 93 \\
U_TR_ME_NO & 4347.8 & 83 \\
U_TR_ME_SO & 6760.5 & 98 \\
U_TR_ME_WE & 10090.0 & 95 \\
\hline
\end{tabular}

When 68 landscape types were searched in the clustered pattern of stone pine, it was concluded that potential distribution of stone pine stands would be expected to cover more than half of the research area. The results found stone pine only exist in the specific area represented with dark grey color, in Figure 4.

The clustered pattern of $P$. pinea $\mathrm{L}$. stands in southern Aydın and northern Muğla provinces were analyzed, and the current distribution of the stands and the distribution of 7 dominant landscape types were mapped. The clustered pattern of $P$. pinea L. stands in southern Aydin and northern Muğla provinces were analyzed, and the current distribution of the stands, and the distribution of 7 dominant landscape types were mapped, in Figure 5.

The evaluation of the structure of these stands is important to understand the distribution of species (McGarigal and Marks, 1995). Within the fourth step of this research, fragmentation among 34 different stands was assessed by landscape metrics, using Fragstats. Class area (CA), Number of Patches (NP), Patch Density (PD), Largest Patch Index (LPI) and Edge Density (ED) were landscape metrics used in this analysis (Table 2).

Comparison of LPI values allows a better understanding of landscape complexity covering stone pine stands at landscape level. Table 3 shows LPI values for the stands. Cfa3, CfCza, Cfcd2, Cfcd1, CfCzd1, Cfa and Cfd1 have a higher value of LPI when compared to other stands. As a result of landscape distribution statistics, Cfc1 has the highest value of NP, while CfSrab2, CfMa, Cfcd2, Cfa have the lowest value respectively. With regard to LPI and PD, Cfd1 obtained the highest value.

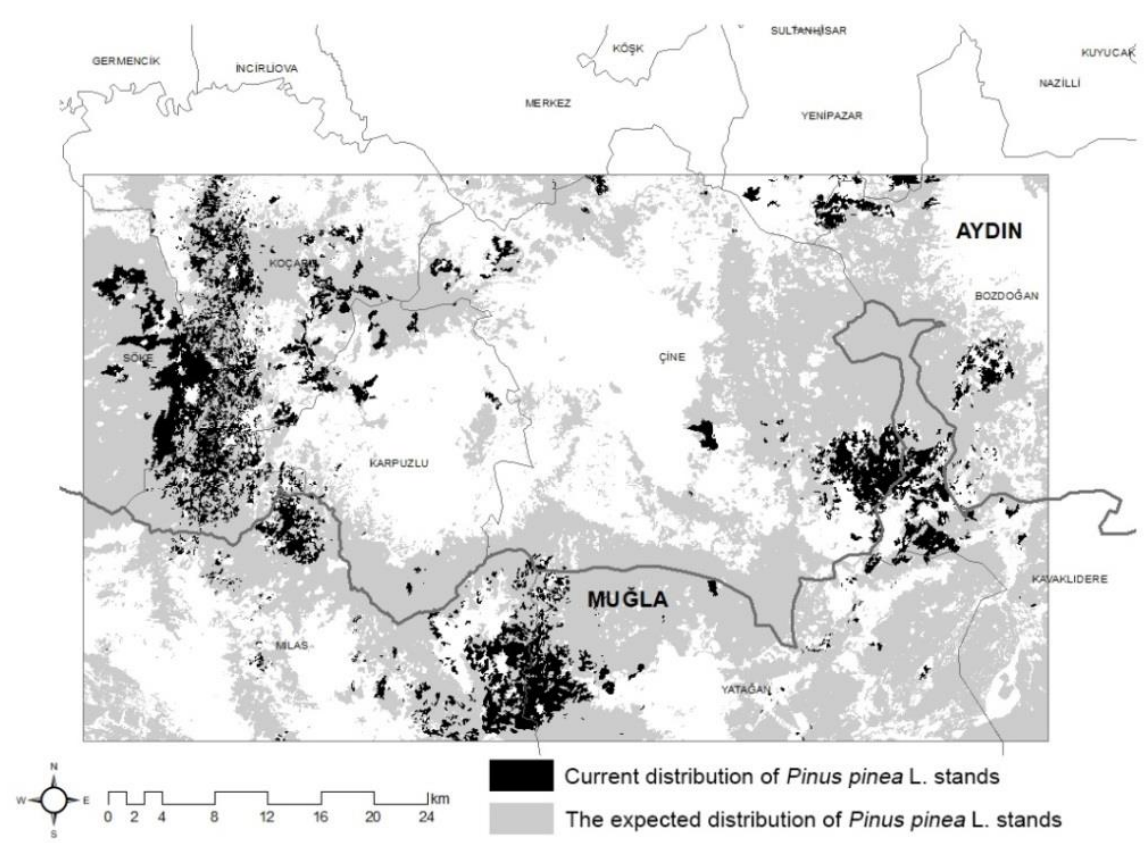

Figure 4. Actual and the potential distribution of $P$. pinea $L$. stands 


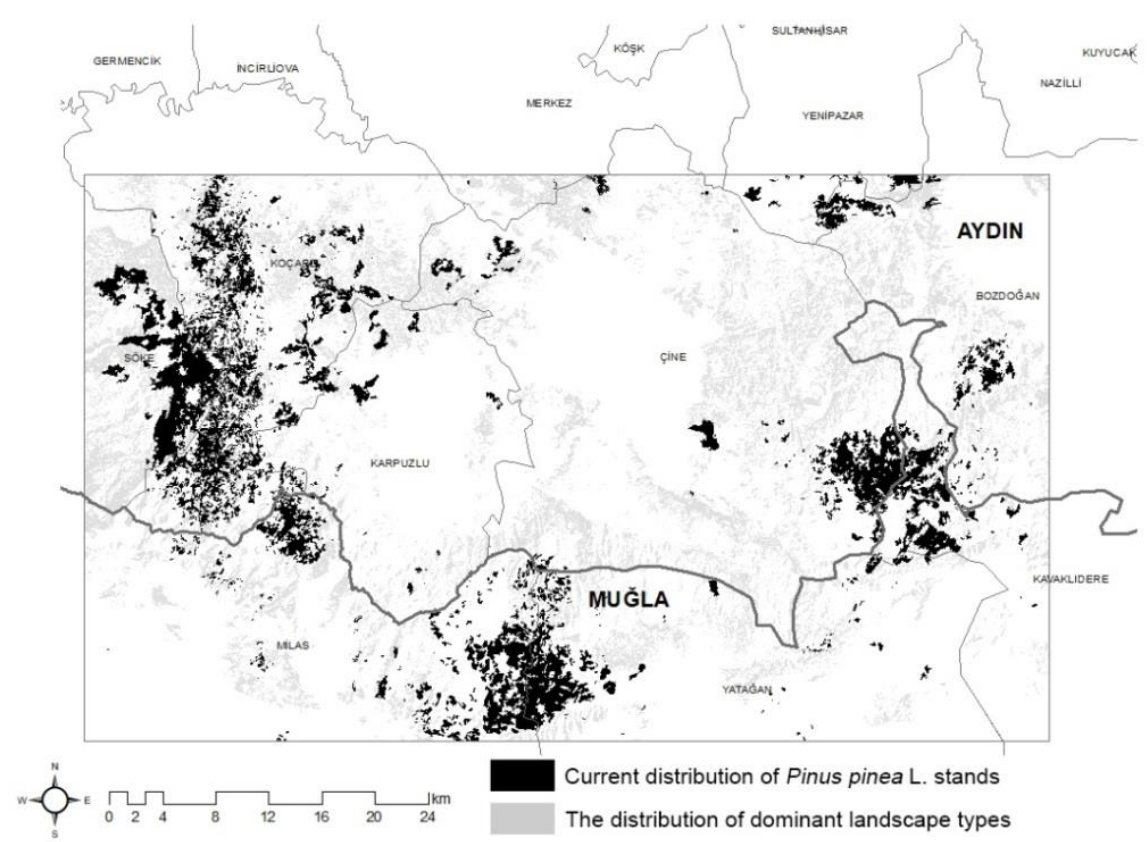

Figure 5. Current distribution of $P$. pinea $\mathrm{L}$. stands with distribution of dominant landscape types

Table 2. Selected landscape metrics at landscape level

\begin{tabular}{ll}
\hline Landscape Metric & Description \\
\hline Class area (CA) & CA defines how much of the landscape is comprised of a particular patch type \\
\hline $\begin{array}{l}\text { Number of Patches (NP) } \\
\text { Patch Density (PD) }\end{array}$ & NP represents landscape configuration \\
\hline Largest Patch Index (LPI) & LPI equals the percentage of the landscape that the largest patch comprises \\
Edge Density (ED) & ED standardizes edge to a per unit area basis that facilitates comparisons among landscapes of varying size \\
\hline
\end{tabular}

Table 3. Landscape metrics results (Cf: stone pine, Cz: brutia pine, Ma: macchia, Sr: cypress, KB: damaged forest, T: rocky ground, a. b. c. d.: Development stages, 1. 2. 3.: Crown closure)

\begin{tabular}{|c|c|c|c|c|c|}
\hline Stand type class & $\mathrm{CA}$ & NP & PD & LPI & ED \\
\hline $\mathrm{CfCza}$ & 5950800.00 & 250000.00 & 0.0015 & 0.01350 & 0.0218 \\
\hline CfMa & 315000.00 & 20000.00 & 0.0001 & 0.00170 & 0.0021 \\
\hline $\mathrm{Cfa}$ & 28904400.00 & 1110000.00 & 0.0066 & 0.02640 & 0.1218 \\
\hline $\mathrm{Cfa} 3$ & 6441300.00 & 130000.00 & 0.0008 & 0.01330 & 0.0259 \\
\hline $\mathrm{CfaO}$ & 4551300.00 & 210000.00 & 0.0012 & 0.00630 & 0.0186 \\
\hline Cfbc1 & 54900.00 & 10000.00 & 0.0001 & 0.00030 & 0.0000 \\
\hline CfCza0 & 582300,00 & 50000.00 & 0.0003 & 0.00160 & 0.0030 \\
\hline Cfb3 & 1257300.00 & 170000.00 & 0.0010 & 0.00170 & 0.0146 \\
\hline Cfab2 & 1321200.00 & 300000.00 & 0.0018 & 0.00150 & 0.0134 \\
\hline $\mathrm{Cfb} 2$ & 65700.00 & 30000.00 & 0.0002 & 0.00030 & 0.0011 \\
\hline Cfbc3 & 636300.00 & 60000.00 & 0.0004 & 0.00270 & 0.0044 \\
\hline CfCzbc 3 & 259200.00 & 30000.00 & 0.0002 & 0.00070 & 0.0003 \\
\hline $\mathrm{Cfc} 3$ & 108900.00 & 30000.00 & 0.0002 & 0.00030 & 0.0013 \\
\hline CfSra & 179100.00 & 30000.00 & 0.0002 & 0.00050 & 0.0014 \\
\hline CfSrab2 & 217800.00 & 30000.00 & 0.0002 & 0.00060 & 0.0028 \\
\hline CfCzab2 & 43200.00 & 10000.00 & 0.0001 & 0.00030 & 0.0006 \\
\hline $\mathrm{Cfc} 2$ & 2493000.00 & 380000.00 & 0.0022 & 0.00160 & 0.0284 \\
\hline Cfd1 & 45403200,00 & 2980000.00 & 0.0176 & 0.03020 & 0.3289 \\
\hline Cfcd1_a & 1933200.00 & 40000.00 & 0.0002 & 0.00680 & 0.0134 \\
\hline CfCzcd2 & 1918800.00 & 210000.00 & 0.0012 & 0.00210 & 0.0228 \\
\hline $\mathrm{Cfd} 2$ & 4307400.00 & 320000.00 & 0.0019 & 0.00520 & 0.0435 \\
\hline CfCzd1 & 11733300.00 & 620000.00 & 0.0037 & 0.01950 & 0.1043 \\
\hline $\mathrm{Cfc1}$ & 929700.00 & 70000.00 & 0.0004 & 0.00180 & 0.0086 \\
\hline Cfcd 2 & 10355400.00 & 670000.00 & 0.0040 & 0.01690 & 0.0926 \\
\hline Cfcd1 & 13507200.00 & 440000.00 & 0.0026 & 0.01720 & 0.0991 \\
\hline CfCzcd1 & 1884600.00 & 150000.00 & 0.0009 & 0.00200 & 0.0186 \\
\hline $\mathrm{CfCzd} 2$ & 5166000.00 & 290000.00 & 0.0017 & 0.00740 & 0.0493 \\
\hline $\mathrm{CfOa}$ & 455400.00 & 20000.00 & 0.0001 & 0.00230 & 0.0025 \\
\hline Cfd_CzCfa & 121500.00 & 20000.00 & 0.0001 & 0.00060 & 0.0019 \\
\hline $\mathrm{CfCz} O \mathrm{a}$ & 190800.00 & 10000.00 & 0.0001 & 0.00110 & 0.0015 \\
\hline Cfd1_T & 540000.00 & 30000.00 & 0.0002 & 0.00230 & 0.0042 \\
\hline $\mathrm{Cfab} \overline{3}$ & 410400.00 & 30000.00 & 0.0002 & 0.00120 & 0.0035 \\
\hline Cfb1_KB & 119700.00 & 10000.00 & 0.0001 & 0.00070 & 0.0002 \\
\hline $\mathrm{CfO}$ & 225000.00 & 20000.00 & 0.0001 & 0.00110 & 0.0006 \\
\hline
\end{tabular}




\section{Discussion}

In this research, we examined the distribution of stone pine forests, and evaluated the stands by LCA to accurately understand the typology. To analyze the structure of the stands, we calculated landscape metrics. This study found that soil type and geological formation were the dominant environmental factors determining distribution of stone pine. Although, slope and aspect values added complexity to distribution, they had a higher impact on landscape fragmentation. The outputs of landscape metrics showed how stone pine forests were fragmented in the research area. Out of 34 stands in total, 10 (Cfd2, Cfa0, Cfcd1_a, CfCzd2, Cfa3, Cfcd2, Cfcd1, CfCzd1, Cfa, Cfd1) had higher value of all the selected metrics. When distribution was examined, the connectivity between landscape patches of each stand was very high. Although the value for LPI was between 0.015 and 0.021 for 8 other stands (Cfab2, CfCza0, Cfc2, CfMa, Cfb3, Cfc1, CfCzcd1, CfCzcd2), their CA, NP, PD, and $\mathrm{ED}$ values were higher than the other stands. Out of these 34 stands, 19 stands were observed as fragmented in the landscape composition. Among 4 variants of the $P$. pinea $L$. community ( $\mathrm{Cf}, \mathrm{CfCz}, \mathrm{CfM}, \mathrm{CfS}), \mathrm{CfM}$, and $\mathrm{CfS}$ were scattered in the research area. As a result of LCA in the clustered pattern of stone pine in the research area, two maps were overlaid in ArcMap 10.5 (forest stands that show all deciduous and evergreen species, and dominant landscape types), and the most suitable areas for regeneration of $P$. pinea $L$. were determined. The potential range for regenerating stone pine stands suggested in this research is illustrated in Figure 6.

Developing and activating strategic interventions is recommended. Strengthening sustainable forest management capacity to protect and regenerate $P$. pinea $\mathrm{L}$. forests is important. Conserving habitats, and preventing further habitat degradation and habitat loss in forests, is a top priority. Healthy forests keep cities healthy; it is especially concerning when species such as $P$. pardus has had drastically increased risk of extinction in Turkey. The findings of this research can guide important decisions for successful forest management and strong sustainability of $P$. pinea $\mathrm{L}$. forests.

Evaluation data on bird species richness, associated with the stone pine forest in the research site, reveals that almost one third of recorded species (7 taxa) are forest specialists (OSIB, 2014). Recorded species of bird fauna in Koçarlı (north of Beşparmak Mountains), and Bozdoğan (vicinity of Madran Mountain), vary as forest specialists, and generalists (Table 4). Stone pine forest communities are concentrated in relatively higher altitudes of the western (Beşparmak Mountains) and eastern Menteşe ranges (Madran Mountain). Certain bird species have sporadic distribution, due to human influence, and geomorphological structures formed by creeks, stream beds, and associated agricultural lands. Connectivity analysis for target species, limited to specific vegetation types rather than the overall landscape mosaic, may be a potential limitation of this research.

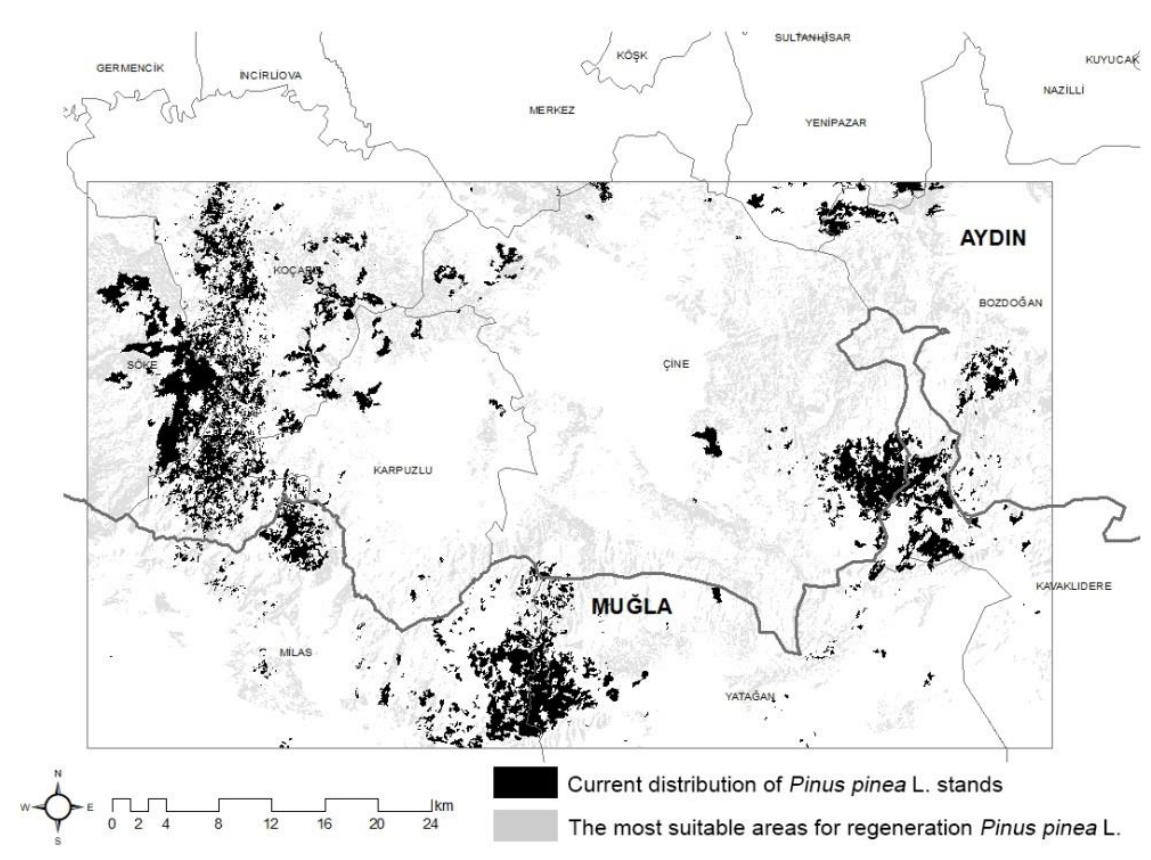

Figure 6. The most suitable areas for regeneration of $P$. pinea $\mathrm{L}$. 
Table 4. Recorded bird species compositions-Koçarlı and Bozdoğan sites (FS: Forest Specialist; FG: Forest Generalist; OT: Pasture, Farmland, and other Human Associated Habitats)

\begin{tabular}{llcc}
\hline \multicolumn{1}{c}{ Bird species } & & Occurrence \\
\cline { 1 - 2 } Koçarl & \multicolumn{1}{c}{ Bozdoğan } & Habitat & $(\%)$ \\
\hline Cyarrulus glandarius & & FS & 8.57 \\
Periparus ater & P. ater & FS & 3.26 \\
Aegithalos caudatus & A. caudatus & FS & 9.38 \\
& Erithacus rubecula & FS & 4.48 \\
& Coccothraustes & FS & 0.81 \\
& coccothraustes & & 0.40 \\
Parus major & Turdus philomelos & FS & \\
Fringilla coelebs & P. major & FG & 17.81 \\
Turdus merula & F. coelebs & FG & 10.61 \\
Corvus corax & T. merula & FG & 13.87 \\
Muscicapa striata & & FG & 2.85 \\
& & FG & 3.26 \\
Emberiza calandra & FG & 0.40 \\
Sylvia melanocephala & & OT & 0.40 \\
Sitta neumayer & S. neumayer & OT & 0.40 \\
Dendrocopos syriacus & D. syriacus & OT & 0.81 \\
Carduelis carduelis & C. carduelis & OT & 5.30 \\
Galerida cristata & & OT & 10.61 \\
Hirundo rustica & OT & 4.48 \\
Passer domesticus & & OT & 0.40 \\
\hline & & OT & 0.40 \\
& & OT & 1.22 \\
\hline
\end{tabular}

Potential range for regenerating stone pine stands, suggested in this study, may be considered as habitat corridors, which would provide connectivity between above mentioned sites. This may promote forest specialist birds, which show relatively low occurrence of enlarging habitat ranges, and increasing population. Saura and Piqué (2006), stated that species richness was favored by more developed forest stages and by tree species diversity, but very dense, closed forest canopies $(>70 \%)$, decreased species richness for both groups forest specialists, and generalists. It is obvious that pine nut ( $P$. pinea $\mathrm{L}$.) production benefits from longer rotations and more open stands, than those optimal for timber production (Gil-Tena et al., 2007). Therefore, establishing stone pine orchards in the farmlands along the habitat corridors, connecting mature stands to each other in the western and eastern Menteşe ranges, may support conservation of avian biodiversity.

LCA is quite new to Turkey as an analysis tool. There have been a few studies using different thematic maps to define landscape types in regional or local scale (Uzun et al., 2011; Yazgi and Yilmaz, 2017). A holistic approach, using a combination of LCA and landscape metrics, was adopted to make a comprehensive evaluation at the landscape level in this research. The connectivity of natural landscapes should be provided by adopting holistic approaches, in order to conserve them and provide their sustainability (Lindenmayer et al., 2002). Despite the fact that there have been various concepts and approaches proposed in the literature about the fragmentation of forests, there is an important need to establish a framework that illustrates the potential distribution of forests and most suitable areas for regeneration of forests, according to the environmental factors.
The key principles for developing this framework are proposed below:

- The composition, configuration and connectivity of landscapes should be clearly defined. For instance, if the focus is on the protection of endangered species, the habitats and their fragmentation pattern should be acquired from the metadata which was produced as a result of LCA.

- Even if Europe has prepared landscape character maps in advance, Turkey is still in the initial phase of producing this inventory. Therefore, a map should be created to show Turkey's core habitats, nature conservation sites and corridors, with links to other map inventories.

- Potential areas for regenerating forests should be mapped considering environmental factors and the fragmentation should be evaluated with specific metrics. How can potential regeneration areas be mapped? Where can the metadata be obtained? Which tools should be used? These questions should be answered to create a rigorous framework.

- How can fragmented landscapes be restored? For example, the potential distribution of a fragmented forest may be mapped according to environmental factors, and landscape metrics can be calculated as demonstrated in this research. The final map illustrates the most suitable areas for regeneration. Who will use this map? Where can restoration begin? What are the legal procedures? Although there are discourses aiming to protect the environment, and provide optimal and sustainable use of natural resources in Turkey, there is no clear plan to implement these provisions. The procedure of restoring fragmented landscapes needs to be clearly explained and activated.

The methodology presented in this research can inspire further research to develop an analytical framework. Rigorous methodology will protect all forest-dwelling wildlife, and especially endangered species with core habitats in the forests.

\section{Acknowledgements}

We thank the Muğla Regional Directorate of Forestry, for providing forest stand maps of the research area, which were very valuable reference materials. Also, special thanks to the Directorate of Zoning, and Urban Planning of Municipal Hall of Aydın, for sharing highly critical, specific data for the research area, including vector maps of soil groups and geological formations.

\section{References}

Abad Viñas, R. A., Caudullo, G., Oliveira, S., de Rigo, D., 2016. Pinus pinea in Europe: Distribution, Habitat, Usage and Threats. European Atlas of Forest Tree Species. Publication Office EU, Luxembourg.

Akkemik, Ü., 2000. Dendroclimatology of umbrella pine (Pinus pinea $\mathrm{L}$.) in Istanbul, Turkey. Tree-Ring Bulletin 56, 17-20.

Alencar, A.A., Brando, P.M., Asner, G.P., Putz, F.E., 2015. Landscape fragmentation, severe drought, and the new Amazon forest fire regime. Ecological applications, 25(6): 1493-1505. 
Antrop, M,, Van Eetvelde, V., 2017. Landscape Perspectives: The Holistic Nature of Landscape. Dordrecht, The Netherlands: Springer.

Ashcroft, M.B., French, K.O., Chisholm, L.A., 2011. An evaluation of environmental factors affecting species distributions. Ecological Modelling, 222(3): 524-531.

Başkaya, Ş., 2003. Pars (Panthera pardus). Orman ve Av Dergisi, 6: 24-30.

Baskaya, S., Bilgili, E., 2004. Does the leopard Panthera pardus still exist in the Eastern Karadeniz Mountains of Turkey? Oryx, 38(2): 228-232.

BirdLife Int, 2018. State of the world's birds indicators for our changing world. http://datazone.birdlife.org/sowb/casestudy/, Accessed: 21.12.2018

Bogaert, J., Barima, Y.S., Iyongo, W.M.L., Bamba, I., Mama, A., Toyi, M., Lafortezza, R., 2011. Forest fragmentation: causes, ecological impacts and implications for landscape management. In: Landscape Ecology in Forest Management and Conservation (Ed: Li, C., Lafortezza, R., Chen, J.), Springer, Berlin, Heidelberg, pp. 273-296.

Bojie, F., Liding, C., 1996. Landscape diversity types and their ecological significance. Acta Geographica Sinica, 5: 454-462.

Boutheina, A., Hedi El Aouni, M., Balandier, P., 2013. Influence of stand and tree attributes and silviculture on cone and seed productions in forests of Pinus pinea L., in northern Tunisia. In Mediterranean stone pine for agroforestry (Ed: Mutke, S., Piqué, M., Calama, R.), Options Mediterraneenes, Zaragoza, pp. 9-14.

Brabyn, L., 2009. Classifying landscape character. Landscape research, 34(3): 299-321.

Broadbent, E.N., Asner, G.P., Keller, M., Knapp, D.E., Oliveira, P.J., Silva, J.N., 2008. Forest fragmentation and edge effects from deforestation and selective logging in the Brazilian Amazon. Biological conservation, 141(7): 1745-1757.

Chakraborty, A., Ghosh, A., Sachdeva, K., Joshi, P.K., 2017. Characterizing fragmentation trends of the Himalayan forests in the Kumaon region of Uttarakhand, India. Ecological Informatics, 38: 95-109.

Cook, E.A., 2002. Landscape structure indices for assessing urban ecological networks. Landscape and urban planning, 58(2-4): 269-280

Crooks, K.R., Burdett, C.L., Theobald, D.M., King, S.R., Di Marco, M., Rondinini, C., Boitani, L, 2017. Quantification of habitat fragmentation reveals extinction risk in terrestrial mammals. Proceedings of the National Academy of Sciences, 114(29): 7635-7640.

Cushman, S.A., McGarigal, K., Neel, M., 2008. Parsimony in landscape metrics: Strength, universality, and consistency. Ecological indicators, 8(5): 691-703.

Dale, V.H., Joyce, L.A., McNulty, S., Neilson, R.P., Ayres, M.P., Flannigan, M.D., Hanson, P.J, Irland, L.C, Lugo, A.E., Peterson, C.J., Simberloff, D., Swanson, F.J., Stocks, B.J., Wotton, B.M., 2001. Climate change and forest disturbances: Climate change can affect forests by altering the frequency, intensity, duration, and timing of fire, drought, introduced species, insect and pathogen outbreaks, hurricanes, windstorms, ice storms, or landslides. BioScience, 51(9): 723-734.

Davidson, C., 1998. Issues in measuring landscape fragmentation. Wildlife Society Bulletin (1973-2006), 26(1): 32-37.

Di Castri, F., 1981. Mediterranean-type shrublands of the world. Mediterranean-Type Shrublands Ecosystems of the World, Vol. 11. Elsevier, Amsterdam, pp. 1-52.

Dušek, R., Popelková, R., 2017. Landscape diversity of the Czech Republic. Journal of Maps. 13, 486-490.

Fahrig, L., 2003. Effects of habitat fragmentation on biodiversity. Annual review of ecology, evolution, and systematics, 34(1): 487-515

Farias, I.P., Santos, W.G., Gordo, M., Hrbek, T., 2015. Effects of forest fragmentation on genetic diversity of the Critically Endangered primate, the pied tamarin (Saguinus bicolor): Implications for conservation. Journal of Heredity, 106(S1): 512521.
Fischer, J., Lindenmayer, D.B., 2007. Landscape modification and habitat fragmentation: A synthesis. Global ecology and biogeography, 16(3): 265-280.

Forman, R.T., 1995. Some general principles of landscape and regional ecology. Landscape Ecology, 10: 133-142.

Forman, R.T., Alexander, L.E., 1998. Roads and their major ecological effects. Annual review of ecology and systematics, 29(1): 207-231.

Forman, R.T., Deblinger, R.D., 2000. The ecological road-effect zone of a Massachusetts (USA) suburban highway. Conservation Biology, 14: 36-46.

Gil-Tena, A., Saura, S., Brotons, L., 2007. Effects of forest composition and structure on bird species richness in a Mediterranean context: Implications for forest ecosystem management. Forest ecology and Management, 242(2-3): 470476

Goodwin, B.J., Fahrig, L., 2002. How does landscape structure influence landscape connectivity? Oikos, 99: 552-570.

Haines-Young, R., Chopping, M., 1996. Quantifying landscape structure: A review of landscape indices and their application to forested landscapes. Progress in physical geography, 20(4): 418445 .

Hamrick, J.L., 2004. Response of forest trees to global environmental changes. Forest ecology and management, 197(1-3): 323-335.

Hargis, C.D., Bissonette, J.A., Turner, D.L., 1999. The influence of forest fragmentation and landscape pattern on American martens. Journal of applied Ecology, 36(1): 157-172.

Hirsch, E., O'Hanlon, M., 1995. The anthropology of landscape: perspectives on place and space. Clarendon Press, Oxford

Kete, R., Yilmaz, I., Karakulak, S., Yildirim, A., 2005. Bafa Gölü çevresi herpetofaunasının çeşitliliği. Anadolu Üniversitesi Bilim ve Teknoloji Dergisi, 6: 87-96.

Kim, K.H., Pauleit, S., 2007. Landscape character, biodiversity and land use planning: The case of Kwangju City Region, South Korea. Land Use Policy, 24: 264-274.

Kumerloeve, H., 1975. Die säugetiere (Mammalia) der Türkei Die säugetiere (Mammalia) Syriens und des Libanon. Veröffentlichungen der Zoologischen Staatssammlung, München, 18: 69-225.

Laurance, W.F., Lovejoy, T.E., Vasconcelos, H.L., Bruna, E.M. Didham, R.K., Stouffer, P.C., Gascon, C., Bierregaard, R.O., Laurance, S.G., Sampaio, E., 2002. Ecosystem decay of Amazonian forest fragments: A 22-year investigation. Conservation Biology, 16(3): 605-618.

Lausch, A., Blaschke, T., Haase, D., Herzog, F., Syrbe, R.U., Tischendorf, L., Walz, U., 2015. Understanding and quantifying landscape structure-A review on relevant process characteristics, data models and landscape metrics. Ecological Modelling, 295: $31-41$

Lindenmayer, D.B., Cunningham, R.B., Donnelly, C.F., Lesslie, R., 2002. On the use of landscape surrogates as ecological indicators in fragmented forests. Forest Ecology and Management, 159(3): 203-216.

Liu, S., Dong, Y., Deng, L., Liu, Q., Zhao, H., Dong, S., 2014. Forest fragmentation and landscape connectivity change associated with road network extension and city expansion: A case study in the Lancang River Valley. Ecological Indicators, 36: 160-168.

Loewe, M., Delard, R., 2012. Un Nuevo Cultivo Para Chile el Pino Pinonero (Pinus pinea L.). Instituto Forestal, Chile.

McAlpine, C.A., Eyre, T.J., 2002. Testing landscape metrics as indicators of habitat loss and fragmentation in continuous eucalypt forests (Queensland, Australia). Landscape Ecology, 17(8): 711-728.

McGarigal, K., Marks, B.J., 1995. FRAGSTATS: Spatial Pattern Analysis Program for Quantifying Landscape Structure. Gen. Tech. Rep. PNW-GTR-351. Portland, OR: US Department of Agriculture, Forest Service, Pacific Northwest Research Station.

McGarigal, K., Tagil, S., Cushman, S.A., 2009. Surface metrics: An alternative to patch metrics for the quantification of landscape structure. Landscape ecology, 24(3): 433-450. 
Midha, N., Mathur, P.K., 2010. Assessment of forest fragmentation in the conservation priority Dudhwa landscape, India using FRAGSTATS computed class level metrics. Journal of the Indian Society of Remote Sensing, 38(3): 487-500.

Muñoz ,V.L., Rodrígue, C.D., Balzarini, M., Contreras, A.Á., Navarro-Cerrillo, R.M., 2015. Impact of climate and management variables on stone pine (Pinus pinea L.) growing in Chile. Agricultural and forest meteorology, 214: 106-116.

Prieur, M., Luginbuehl, Y., Zoido Naranjo, F., De Montmollin, B., Pedroli B, Van Mansvelt, J.D., Durousseau, S., 2006. Landscape and Sustainable Development-Challenges of the European Landscape Convention. Council of Europe Publishing, Strasbourg.

Qian, J., Xiang, W.N., Liu, Y., Meng, X., 2018. Incorporating landscape diversity into greenway alignment planning. Urban Forestry \& Urban Greening, 35: 45-56.

OSIB, 2014. Orman ve Su İșleri Bakanliği Doğa Koruma ve Milli Parklar Genel Müdürlüğü IV. Bölge Müdürlüğü, Ulusal Biyolojik Çeşitlilik Envanter ve İzleme Projesi. Aydın İl Şube Müdürlüğü. Aydın İli'nin Karasal Biyolojik Çeşitlilik ve İç Su Ekosistemleri Biyolojik Çeşitlilik Envanter ve İzleme İşi Sonuç Raporu, s. 63-70.

Richardson, D.M., 1998. Ecology and Biogeography of Pinus. Cambridge University Press, New York.

Riitters, K.H., O'neill, R.nV., Hunsaker, C.T., Wickham, J.D., Yankee, D.H., Timmins, S.P., Jones, K.B., Jackson, B.L., 1995. A factor analysis of landscape pattern and structure metrics. Landscape ecology, 10(1): 23-39.

Rocha-Santos, L., Pessoa, M.S., Cassano, C.R., Talora, D.C., Orihuela, R.L.L., Mariano-Netos, E., Morante-Filho, J.C., Faria, D., Cazetta, E., 2016. The shrinkage of a forest: landscape-sacale deforestation leading to overall changes in local forest structure. Biological Conservation: 196, 1-9.

Romero, Y., Gilsanz, F., 1888. Cría, Cultivo y Aprovechamiento Del Pino Pinonero. Universal Fair of Barcelona. Madrid, Spain.

Rosati, L., Fipaldini, M., Marignani, M., Blasi, C., 2010. Effects of fragmentation on vascular plant diversity in a Mediterranean forest archipelago. Plant Biosystems, 144(1): 38-46.

Saunders, D.A., Hobbs, R.J., Margules, C.R., 1991. Biological consequences of ecosystem fragmentation: A review. Conservation biology, 5(1): 18-32.

Saura, S., Piqué, M., 2006. Forests and Forest Sector in Catalonia. Agriculture and Agri-food Production in Perspective: Profile of the Sector in Catalonia. University of Lleida, Lleida.

Scarascia-Mugnozzaa, G., Oswald, H., Piussic, P., Radogloud, K., 2000. Forests of the Mediterranean region: Gaps in knowledge and research needs. Forest Ecology and Management, 132(1): 97-109.

Schnell, J.K., Harris, G.M., Pimm, S.L., Russell, G.J., 2013. Quantitative analysis of forest fragmentation in the Atlantic Forest reveals more threatened bird species than the current Red List. PLoS One, 8: 1-8.

Secmen, O., Leblebici, E., 1982. Batı Anadolu sucul vegatasyonu. IX Ulusal Biyoloji Kongresi Genel ve Sistematik Botanik Seksiyonları, Cilt 3, Cumhuriyet Üniversitesi, Sivas, s. 369-381.

Simensen, T., Halvorsen, R., Erikstad, L., 2018. Methods for landscape characterisation and mapping: A systematic review. Land Use Policy, 75: 557-569.

Sulieman, H.M., 2018. Exploring drivers of forest degradation and fragmentation in Sudan: the case of Erawashda forest and its surrounding community. Science of the Total Environment, 621: 895-904.
Swanwick, C., 2002. Landscape character assessment. Guidance for England and Scotland. The Countryside Agency and Scottish Natural Heritage, http://www.heritagecouncil.ie/fileadmin/user _upload/Planning/LCA_CPD/LC, Accessed: 15.05.2018.

Taylor, P.D., Fahrig, L., Henein, K., Merriam, G., 1993. Connectivity is a vital element of landscape structure. Oikos, 68: 571-573.

Trumbore, S., Brando, P., Hartmann, H., 2015. Forest health and global change. Science, 349: 814-818.

Tudor, C., 2014. An approach to landscape character assessment https://assets.publishing.service.gov.uk/government/uploads/syst em/uploads/attachment_data/file/691184/landscape-characterassessment.pdf, Accessed: 23.06.2018.

Uuemaa, E., Antrop, M., Roosaare, J., Marja, R., Mander, Ü., 2009. Landscape metrics and indices: An overview of their use in landscape research. Living reviews in landscape research, 3(1): $1-28$.

Uzun, O., Dilek, F., Çetinkaya, D., Erduran, F., Açıksöz, S., 2011. National and regional landscape classification and mapping of Turkey: Konya closed basin, Suğla Lake and its surrounding area. International Journal of Physical Sciences, 6(3): 550-565.

Varol, O., 2004. Phytosociological Investigations of Pinus pinea L. Forests in the Southwestern Anatolia Region of Turkey. Israel Journal of Plant Sciences, 52: 65-70.

Varol, O., Karaer, F., Terzioğlu, S., Kutbay, G., 2003. Phytosociological investigations of Pinus pinea L. forests in the North-East Anatolia region (Trabzon and Artvin-Turkey). Pakistan Journal of Botany, 35: 587-595.

Varol, O., Tatli., A., 2002. Phytosociological investigations of a Pinus pinea L. forest in the Eastern Mediterranean Region (K. Maraş-Turkey). Plant Ecology, 158: 223-228.

Varol, O., Tel, A.Z., 2010. Ecological features of the Pinus pinea forests in the north-west region of Turkey (Yalova). Ekoloji, 19: 95-101.

Wang, X., Blanchet, F.G., Koper, N., 2014. Measuring habitat fragmentation: An evaluation of landscape pattern metrics. Methods in Ecology and Evolution, 5(7): 634-646.

Wascher, D.M., 2005. European Landscape Character AreasTypologies, Cartography and Indicators for the Assessment of Sustainable Landscapes. Final Project Report as deliverable from the EU's Accompanying Measure project European Landscape Character Assessment Initiative (ELCAI), funded under the 5th Framework Programme on Energy, Environment and Sustainable Development, http://library.wur.nl/WebQuery/wurpubs/fulltext/ 1778, Accessed: 12.04.2018.

Wilcove, D.S., McLellan, C.H., Dobson, A.P., 1986. Habitat fragmentation in the temperate zone. Conservation biology, 6: 237-256.

Williams-Linera, G., 1990. Vegetation structure and environmental conditions of forest edges in Panama. The Journal of Ecology, pp. 356-373.

Yazgi, D., Yilmaz, K.T., 2017. The evaluation of landscape typology and richness for achieving conservation priorities of habitats. Proceedings of the Ecology 2017 International Symposium, 1113 May, Kayseri, Turkey. pp. 309-318.

Zohary, M., 1973. Geobotanical Foundations of the Middle East, Vol. I-II. Gustav Fischer Verlag, Stutgart.

Zube, E.H., Sell, J.L., Taylor, J.G., 1982. Landscape perception: research, application and theory. Landscape planning, 9(1): 1-33. 